\title{
RALB wt Allele
}

National Cancer Institute

\section{Source}

National Cancer Institute. RALB wt Allele. NCI Thesaurus. Code C52544.

Human RALB wild-type allele is located within 2cen-q13 and is approximately $42 \mathrm{~kb}$ in length. This allele, which encodes Ras-related protein Ral-B, is involved in the regulation of signaling pathways that respond to the occupancy of cell surface receptors. 